\section{Narcissus Response to Plant Growth Regulators}

\author{
Brian A. Krug, Brian E. Whipker ${ }^{1}$, Ingram McCall, and \\ John M. Dole
}

AdDitional IndEx words. Bonzi, 'Dutch Master', ethephon, Florel, flurprimidol, Narcissus pseudonarcissus, paclobutrazol, Piccolo, 'Sweetness', 'Tete a Tete', Topflor

\begin{abstract}
SUMMARY. Three experiments were conducted to determine the effectiveness of plant growth regulators (PGRs) on 'Tete a Tete', 'Dutch Master', and 'Sweetness' narcissus (Narcissus pseudonarcissus). Ethephon foliar sprays (500 to 2500 $\left.\mathrm{mg} \cdot \mathrm{L}^{-1}\right)$ and substrate drenches of flurprimidol and paclobutrazol $(0.25$ to $4 \mathrm{mg} /$ pot a.i.) did not control height during greenhouse forcing of 'Tete a Tete' at any concentration trialed. Stem stretch was controlled during postharvest evaluation with ethephon foliar sprays $\geq 1000 \mathrm{mg} \cdot \mathrm{L}^{-1}$, flurprimidol substrate drenches $\geq 0.5$ $\mathrm{mg} /$ pot a.i., and paclobutrazol substrate drenches of $4 \mathrm{mg} /$ pot a.i. A second experiment investigated preplant bulb soaks of flurprimidol $\left(10\right.$ to $\left.40 \mathrm{mg} \cdot \mathrm{L}^{-1}\right)$ applied to 'Dutch Master' and 'Tete a Tete' narcissus bulbs. Flurprimidol preplant bulb soaks controlled postharvest stretch on 'Tete a Tete' and 'Dutch Master' at concentrations $\geq 15$ and $\geq 10 \mathrm{mg} \cdot \mathrm{L}^{-1}$, respectively. A third experiment was conducted with paclobutrazol ( 75 to $\left.375 \mathrm{mg} \cdot \mathrm{L}^{-1}\right)$ on 'Tete a Tete' and 'Dutch Master' and three concentrations of flurprimidol on 'Sweetness' to determine optimal soak recommendations. Paclobutrazol preplant bulb soaks $\geq 75 \mathrm{mg} \cdot \mathrm{L}^{-1}$ controlled postharvest stretch of 'Tete a Tete' and 'Dutch Master', while $37.5 \mathrm{mg} \cdot \mathrm{L}^{-1}$ of flurprimidol controlled postharvest stretch of 'Sweetness'. Based on the results of these experiments, growers can now select a PGR to help control excessive plant growth.
\end{abstract}

$\mathrm{W}$ hen narcissus are grown in pots, a common problem encountered by growers is excessive plant height (Briggs, 1975; Moe, 1980). Typically, taller cultivars are grown in 6-inch-diameter pots and shorter cultivars are grown in 4inch-diameter pots. Optimal height for plants grown in 6-inch pots at the "pencil" stage should be 10 to 12 inches tall; however, cultivars grown in 4-inch pots at the same stage should be shorter (De Hertogh, 1996). Plant growth regulators can be used to produce plants at the appropriate height. Ethephon is commonly used as a foliar spray at concentrations of 1000 to $2000 \mathrm{mg} \cdot \mathrm{L}^{-1}$ when the leaves and floral stalks are 3 to 4 inches tall (De Hertogh, 1996; Kamp and De Hertogh, 1986). Paclobutrazol (Bonzi; Syngenta, Greensboro, N.C.) label

Department of Horticultural Science, Box 7609, North Carolina State University, Raleigh, NC 27695-7609.

Use of trade names in this publication does not imply endorsement of products named nor criticism of similar ones not mentioned. Thanks to Berger for the root substrates, Scotts for the fertilizer, Dillen Products for the pots, and SePRO Co. for grant support.

${ }^{1}$ To whom reprint requests should be addressed; e-mail address: brian_whipker@ncsu.edu recommendations include drench applications of 1.2 to $2.4 \mathrm{mg} /$ pot a.i. 1 to $5 \mathrm{~d}$ after removal from the cooler, or a 1 -h preplant soak at a concentration of $80 \mathrm{mg} \cdot \mathrm{L}^{-1}$; however, it has been reported that paclobutrazol is only marginally effective in controlling height (Adriansen, 1985). Bulb crops are listed on the uniconazole (Sumagic; Valent USA, Marysville, Ohio) label; however, for narcissus no specific recommendations are given, and it has been reported to have limited effectiveness (W.B. Miller, personal communication). Flurprimidol (Topflor; SePRO Corp., Carmel, Ind.) has been available in Europe for more than 20 years as a $1.47 \%$ concentration and is being introduced into the U.S. market as a $0.38 \%$ concentration.
These experiments were conducted to determine the efficacy of flurprimidol $(0.38 \%)$ applied as a substrate drench compared to paclobutrazol substrate drenches and ethephon foliar sprays on 'Tete a Tete' narcissus. The optimum concentration for flurprimidol preplant bulb soaks on 'Tete a Tete', 'Dutch Master', and 'Sweetness' narcissus were investigated as well as optimum concentrations of paclobutrazol on 'Tete a Tete' and 'Dutch Master' as preplant bulb soaks.

\section{Methods and materials}

ЕхРт. 1. On 25 Oct. 2002, noncooled narcissus 'Tete a Tete' bulbs were planted, two bulbs per pot, in 4 -inch-diameter round plastic pots with a volume of $575 \mathrm{~mL}$. The root substrate was Berger BM 6 (Berger Peat Moss, St. Modeste, Que., Canada), which contained $75 \%$ to $80 \%$ Canadian sphagnum peat and $20 \%$ to $25 \%$ perlite. For 10 weeks the cooler temperature set point was $41^{\circ} \mathrm{F}$. On 4 Jan. 2003 the cooler temperature set point was reduced to $34^{\circ} \mathrm{F}$ until $8 \mathrm{Feb} .2003$. The bulbs were removed from the cooler at sunset and allowed to acclimate overnight. Greenhouse forcing began on 8 Feb. 2003 with day/night set points of $68 / 64^{\circ} \mathrm{F}$. Plants were forced under natural day lengths.

On 9 Feb. 2003, substrate drenches were applied at $2 \mathrm{fl} \mathrm{oz}$ solution per pot: flurprimidol $(0.38 \%)$ at $0.25,0.5$, 1,2 , or $4 \mathrm{mg} /$ pot a.i.; and paclobutrazol (Piccolo; Fine Americas, Walnut Creek, Calif.) at $0.25,0.5,1,2$, or 4 $\mathrm{mg} /$ pot a.i. Foliar sprays of ethephon at $500,1000,1500,2000$, or 2500 $\mathrm{mg} \cdot \mathrm{L}^{-1}$ were also applied at $0.5 \mathrm{gal} / 100$ $\mathrm{ft}^{2}$ on 9 Feb., when the shoots were 3 to 4 inches tall. Untreated controls were also included. The experiment was a completely randomized design with six single-pot replications for each of the 16 treatments.

Expт. 2. On 24 Oct. 2003, dry, noncooled 'Tete a Tete' and 'Dutch Master' were soaked for $10 \mathrm{~min}$ in

\begin{tabular}{llll}
\hline $\begin{array}{l}\text { Units } \\
\begin{array}{l}\text { To convert U.S. to SI, } \\
\text { multiply by }\end{array}\end{array}$ & U.S. unit & SI unit & $\begin{array}{l}\text { To convert SI to U.S., } \\
\text { multiply by }\end{array}$ \\
\hline 29.5735 & $\mathrm{fl} \mathrm{oz}$ & $\mathrm{mL}$ & 0.0338 \\
3.7854 & $\mathrm{gal}$ & $\mathrm{L}$ & 0.2642 \\
0.4075 & $\mathrm{gal} / 100 \mathrm{ft}^{2}$ & $\mathrm{~L} \cdot \mathrm{m}^{-2}$ & 2.4542 \\
2.5400 & inch $(\mathrm{es})$ & $\mathrm{cm}$ & 0.3937 \\
28,350 & $\mathrm{oz}$ & $\mathrm{mg}$ & $3.5274 \times 10^{-5}$ \\
1 & $\mathrm{ppm}$ & $\mathrm{mg} \cdot \mathrm{L}^{-1}$ & 1 \\
$\left({ }^{\circ} \mathrm{F}-32\right) \div 1.8$ & ${ }^{\circ} \mathrm{F}$ & ${ }^{\circ} \mathrm{C}$ & $\left(1.8 \times{ }^{\circ} \mathrm{C}\right)+32$
\end{tabular}


flurprimidol $(0.38 \%)$ at $10,15,20$, $25,30,35$, or $40 \mathrm{mg} \cdot \mathrm{L}^{-1}$. Tap water was used to mix the soak solution at a temperature of $64^{\circ} \mathrm{F}$. Untreated controls were also included. The 'Tete a Tete' bulbs were allowed to air dry and were planted, two bulbs per pot, in 4-inch-diameter round plastic pots with a volume of $575 \mathrm{~mL}$ on the day of treatment. Narcissus 'Dutch Master' bulbs were also allowed to air dry and were planted, two bulbs per pot, in 6inch-diameter round plastic pots with a volume of $1.9 \mathrm{~L}$. The root substrate was Berger BM 6. The experiment was a completely randomized design with six single-pot replications for each of the eight treatments. For 10 weeks the cooler temperature set point was $41^{\circ} \mathrm{F}$. On 5 Jan. 2004 the cooler temperature set point was reduced to $34^{\circ} \mathrm{F}$ until 5 Feb. 2004. The pots were removed from the cooler and allowed to acclimate overnight. Greenhouse forcing began on 5 Feb. 2004 with day/night set points of $68 / 64{ }^{\circ} \mathrm{F}$. Plants were forced under natural day lengths.

Ехрт. 3. On 28 Oct. 2004, dry, noncooled 'Tete a Tete' and 'Dutch Master' bulbs were soaked in paclobutrazol (Bonzi) for $2 \mathrm{~min}$ at 75 , $150,225,300$, or $375 \mathrm{mg} \cdot \mathrm{L}^{-1}$. Tap water was used to mix the soak solution at a temperature of $70{ }^{\circ} \mathrm{F}$. Noncooled 'Sweetness' bulbs were soaked in flurprimidol for $2 \mathrm{~min}$ at $25,37.5$, or $50 \mathrm{mg} \cdot \mathrm{L}^{-1}$. Untreated controls were also included. The 'Tete a Tete', 'Dutch Master', and 'Sweetness' bulbs were allowed to air dry and were planted as described in Expt. 2. The experiment was a completely randomized design with eight single-pot replications of

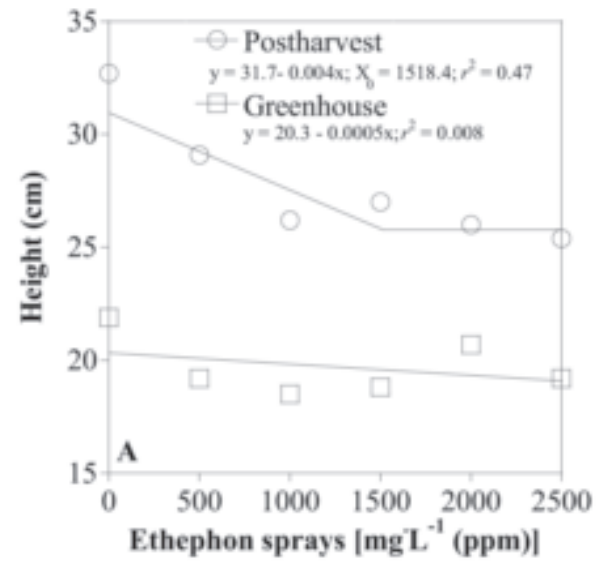

10 treatments. From potting to 4 Jan. 2005 , bulbs were held at $41^{\circ} \mathrm{F}$. On 4 Jan. 2005 the cooler temperature set point was reduced to $34^{\circ} \mathrm{F}$ until 14 Feb. 2005. Greenhouse forcing began on $14 \mathrm{Feb}$. with day/night set points of $68 / 65^{\circ} \mathrm{F}$. Plants were forced under natural day lengths.

GreENHOUSE DATA COLLECTION. Anthesis date (one inflorescence per pot fully opened) and plant height at anthesis (measured from the soil line to the uppermost part of the inflorescence) were recorded.

Postharvest evaluation. Four randomly selected plants from each treatment and each experiment were placed in a postharvest room at 68 ${ }^{\circ} \mathrm{F}$ after anthesis. Light was provided by fluorescent bulbs at 24 to 75 $\mu \mathrm{mol} \cdot \mathrm{m}^{-2} \cdot \mathrm{s}^{-1}$. Plant height was recorded $8 \mathrm{~d}$ (Expt. 1) and $10 \mathrm{~d}$ (Expt. 2 and Expt. 3) after anthesis.

Data ANALYsis. Data were tested by analysis of variance (ANOVA) using general linear model (SAS Institute, Cary, N.C.) and means were separated by least significant differences (LSD) at $P \leq 0.05$. Plant heights at the end of forcing were regressed using PROC REG to determine the best-fit, linear or quadratic models. Terms of the model were evaluated for significance based on comparison of $\mathrm{F}$ values at $\propto=0.05$. PROC NLIN in SAS, as modified by Cox (1992), was used to calculate linear-plateau functions (model IV) relating postharvest plant height to ethephon, flurprimidol, and paclobutrazol concentrations. The quadratic and the linear-plateau models were compared to determine the best fit based on $r^{2}$ values.

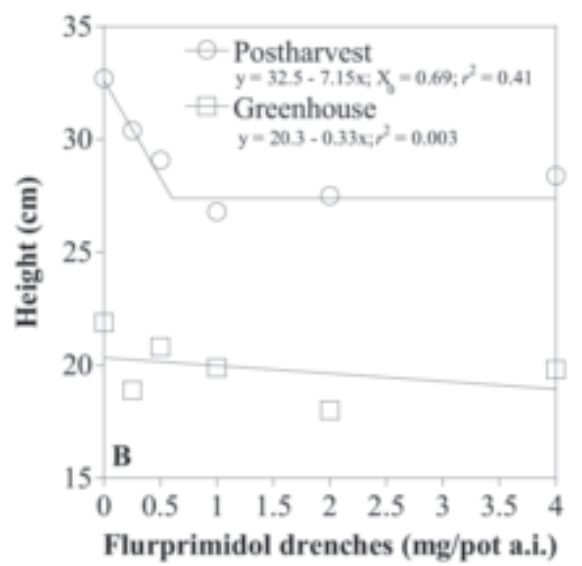

\section{Results and discussion}

Expt. 1. Plant height of 'Tete a Tete' narcissus during greenhouse forcing was not controlled with ethephon foliar sprays at any concentration used (Fig. 1A). At the end of the postharvest evaluation, the response of 'Tete a Tete' narcissus plants to ethephon foliar sprays was best fit to a linearplateau model in which the smallest plants $(25.7 \mathrm{~cm}$ tall $)$ occurred with sprays of $1518.4 \mathrm{mg} \cdot \mathrm{L}^{-1}$ (Fig. 1A). No further increases in height control occurred at higher concentrations. Plants treated with $1518.4 \mathrm{mg} \cdot \mathrm{L}^{-1}$ ethephon were $19 \%$ shorter than the untreated control. Ethephon foliar sprays did not result in delay of anthesis at any concentration trialed (data not shown). Ethephon foliar sprays of $1518.4 \mathrm{mg} \cdot \mathrm{L}^{-1}$ are within the 1000 to $2000 \mathrm{mg} \cdot \mathrm{L}^{-1}$ range recommended by De Hertogh (1996) to maintain a marketable plant height.

Flurprimidol substrate drenches did not significantly $(P \leq 0.05)$ control plant height at any concentration trialed during greenhouse forcing (Fig. $1 B)$. At the end of the postharvest evaluation, the response of 'Tete a Tete' narcissus plants to flurprimidol substrate drenches was best fit to a linear-plateau model in which the smallest plants $(27.6 \mathrm{~cm}$ tall $)$ resulted from drenches of $0.69 \mathrm{mg}$ /pot a.i. (Fig. 1B). No further increases in height control occurred at higher concentrations. Plants treated with $0.69 \mathrm{mg} / \mathrm{pot}$ a.i. flurprimidol were $15 \%$ shorter than the untreated control. Flurprimidol substrate drenches did not delay anthesis at any concentration trialed (data

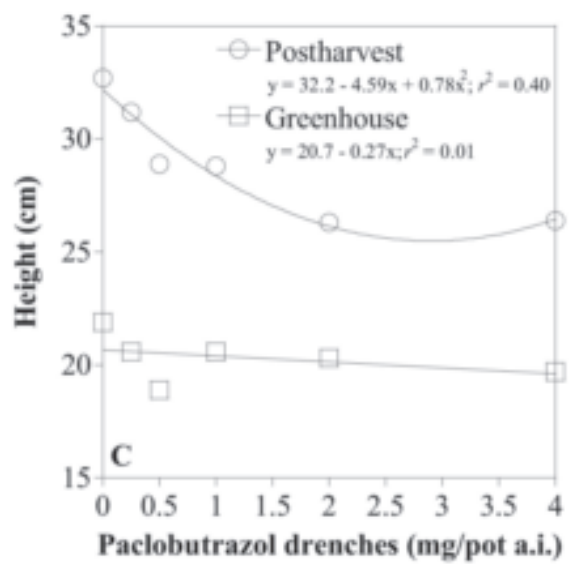

Fig. 1. Effects of ethephon foliar sprays (A), flurprimidol substrate drenches (B) and paclobutrazol substrate drenches (C) on pot narcissus 'Tete a Tete' height measured at anthesis (Greenhouse) and $8 \mathrm{~d}$ after anthesis (Postharvest) (Expt. 1 ) (1 cm $=0.3937$ inch, $\left.1 \mathrm{mg}=3.5274 \times 10^{-5} \mathrm{oz}\right)$. 

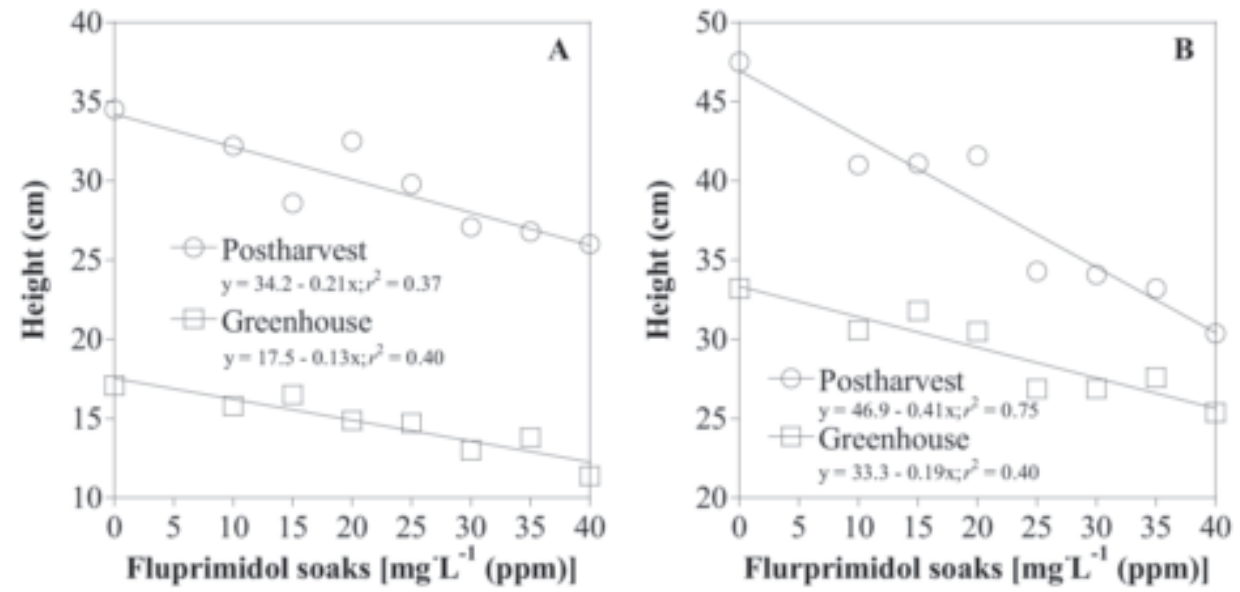

Fig. 2. Effects of flurprimidol preplant bulb soaks on narcissus cultivars 'Tete a Tete' (A, above left) and 'Dutch Master' (B, above right) plant height measured at anthesis (Greenhouse) and $10 \mathrm{~d}$ after anthesis (Postharvest) $($ Expt. 2$)(1 \mathrm{~cm}=0.3937$ inch).

not shown). Based on these results, flurprimidol at concentration of 0.69 $\mathrm{mg} /$ pot a.i. can be used as a substrate drench by growers who want to control postharvest stem stretch of 'Tete a Tete' narcissus grown in 4 -inch pots.

Paclobutrazol substrate drenches did not control plant height at any concentration trialed during greenhouse forcing (Fig. 1C). Postharvest stem stretch of 'Tete a Tete' narcissus plants was controlled by paclobutrazol substrate drenches at a concentration of $2 \mathrm{mg} /$ pot a.i. This resulted in plants $26.1 \mathrm{~cm}$ tall, which were 19\% shorter than the untreated control (Fig. 1C). No concentration of paclobutrazol substrate drenches delayed anthesis (data not shown). Paclobutrazol substrate drenches of $2 \mathrm{mg} /$ pot a.i. were within the 1.2 to $2.4 \mathrm{mg} /$ pot a.i. listed on the paclobutrazol label.

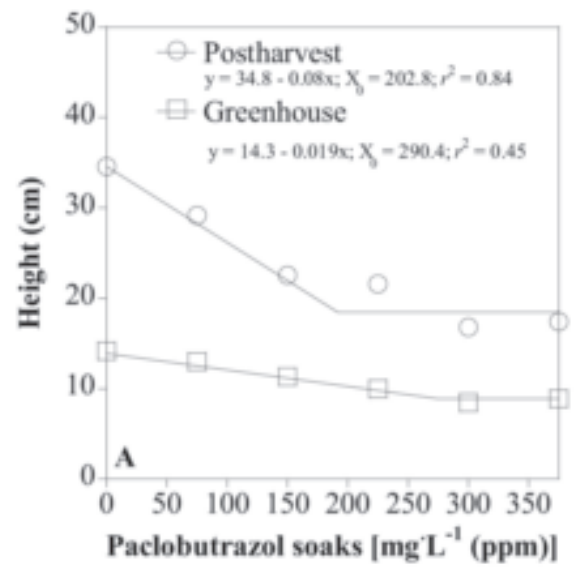

ExPT. 2. Flurprimidol preplant bulb soaks significantly $(P \leq 0.05)$ controlled 'Tete a Tete' and 'Dutch Master' plant height during greenhouse forcing at concentrations $\geq 25$ $\mathrm{mg} \cdot \mathrm{L}^{-1}$, which resulted in plants $\geq 19 \%$ and $\geq 14 \%$ shorter than the untreated control, respectively (Fig. 2A-B). No delay of anthesis occurred with any concentration of flurprimidol trialed for either cultivar (data not shown). Stem stretch of 'Tete a Tete' and 'Dutch Master' was controlled during the postharvest evaluation with flurprimidol preplant bulb soaks $\geq 25$ $\mathrm{mg} \cdot \mathrm{L}^{-1}$ and $\geq 20 \mathrm{mg} \cdot \mathrm{L}^{-1}$, respectively. These concentrations resulted in 'Tete a Tete' plants that were $\geq 15 \%$ shorter and 'Dutch Master' plants $\geq 18 \%$ shorter than the untreated control (Fig. 2A-B). Flurprimidol preplant bulb soaks can be used to control postharvest stem

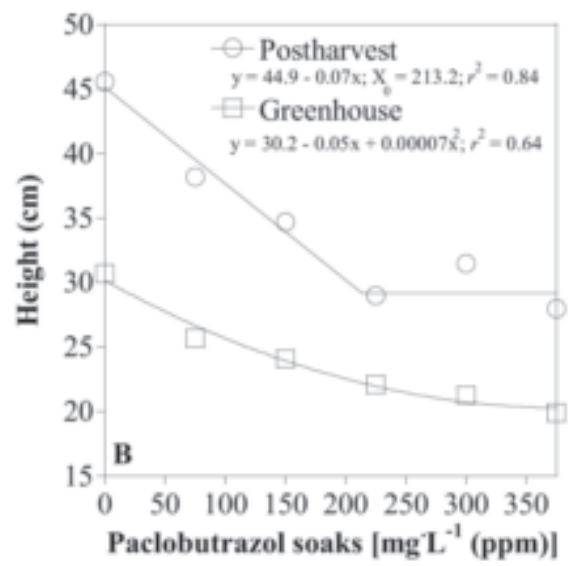

stretch of 'Tete a Tete' and 'Dutch Master' at concentrations of 25 and $20 \mathrm{mg} \cdot \mathrm{L}^{-1}$, respectively.

ExPT. 3. Paclobutrazol preplant bulb soaks significantly $(P \leq 0.05)$ controlled 'Tete a Tete' narcissus plant height during greenhouse forcing at concentrations $\geq 150 \mathrm{mg} \cdot \mathrm{L}^{-1}$, resulting in plants at least $20 \%$ shorter than the untreated control (Fig. 3A). At concentrations $\geq 150 \mathrm{mg} \cdot \mathrm{L}^{-1}$, anthesis was delayed by $0.5 \mathrm{~d}(P \leq 0.05)$, which would not be considered excessive by commercial standards. Based on linear plateau analysis, the use of $\geq 202.8$ $\mathrm{mg} \cdot \mathrm{L}^{-1}$ of paclobutrazol resulted in 'Tete a Tete' plants that were $18.6 \mathrm{~cm}$ tall at the end of the postharvest evaluation (Fig 3A). These plants were 47\% shorter than the untreated control. No further increases in control occurred at higher concentrations. Although

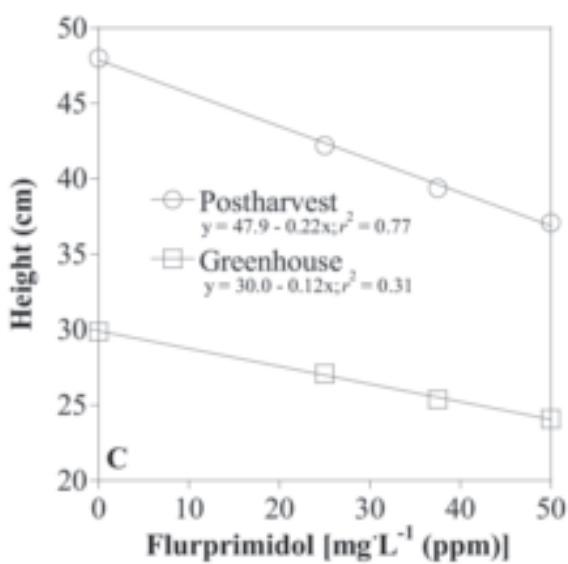

Fig. 3. Effects of preplant bulb soaks on narcissus cultivars using paclobutrazol on 'Tete a Tete' (A, above left) and 'Dutch Master' (B, above center), and flurprimidol on 'Sweetness' (C, above right) plant height measured at anthesis (Greenhouse) and $10 \mathrm{~d}$ after anthesis (Postharvest) (Expt. 3) $(1 \mathrm{~cm}=0.3937 \mathrm{inch})$. 
the greatest control was provided by a concentration of $202.8 \mathrm{mg} \cdot \mathrm{L}^{-1}$, this would be considered excessive by commercial standards. A concentration of $75 \mathrm{mg} \cdot \mathrm{L}^{-1}$ would be considered commercially acceptable, which resulted in plants $17 \%$ shorter than the untreated control.

Paclobutrazol preplant bulb soaks controlled 'Dutch Master' narcissus plant height during greenhouse forcing at concentrations $\geq 75 \mathrm{mg} \cdot \mathrm{L}^{-1}$, resulting in plants at least $11 \%$ shorter than the untreated control (Fig. 3B). All concentrations with the exception of $150 \mathrm{mg} \cdot \mathrm{L}^{-1}$ delayed anthesis by $\mathrm{l}$ to $1.5 \mathrm{~d},(P \leq 0.05)$, which would not be considered excessive by commercial standards. At the end of the postharvest evaluation, plants treated with concentrations $\geq 213.2 \mathrm{mg} \cdot \mathrm{L}^{-1}$ were $30.0 \mathrm{~cm}$ tall $(33 \%$ shorter than the untreated control) (Fig. 3B). No further increases in control occurred at higher concentrations. The control provided by $213.2 \mathrm{mg} \cdot \mathrm{L}^{-1}$ would be considered excessive by commercial standards. Based on regression analysis, a concentration of $100 \mathrm{mg} \cdot \mathrm{L}^{-1}$ resulted in plants $37.9 \mathrm{~cm}$ tall ( $16 \%$ shorter than the untreated control) and would be considered commercially acceptable.

The paclobutrazol (Bonzi) label recommended an $80 \mathrm{mg} \cdot \mathrm{L}^{-1}$ bulb soak for $1 \mathrm{~h}$; however, our recommendation of $100 \mathrm{mg} \cdot \mathrm{L}^{-1}$ required only a 2 -min soak time. It is unclear why a lower rate was recommended with the longer soak time. Varying soak time for 2 to 40 min with flurprimidol was reported to have no effect on the plant height of hyacinth (Hyacinthusorientalis) (Krug, 2004). The shorter soak time would be beneficial in saving labor costs during the soak process.

Flurprimidol preplant bulb soaks controlled 'Sweetness' narcissus plant height during greenhouse forcing at concentrations $\geq 37.5 \mathrm{mg} \cdot \mathrm{L}^{-1}$, resulting in plants at least $15 \%$ shorter than untreated controls (Fig. 3C). No delay of anthesis was caused by any concen- tration trialed (data not shown). At the end of the postharvest evaluation, plants treated with a concentration $\geq 25 \mathrm{mg} \cdot \mathrm{L}^{-1}$ were significantly shorter than the untreated control $(P \leq 0.05)$; however, a concentration of 37.5 $\mathrm{mg} \cdot \mathrm{L}^{-1}$ resulted in plants that were commercially acceptable (17\% shorter than the untreated control).

\section{Conclusions}

'Tete a Tete' plant height was not controlled by ethephon foliar sprays, flurprimidol substrate drenches, or paclobutrazol substrate drenches during greenhouse forcing. Only preplant bulb soaks of flurprimidol and paclobutrazol were effective in providing shorter 'Tete a Tete' and 'Dutch Master' plants in the greenhouse. However, height control is often not a concern for commercial producers during greenhouse forcing, as the plants are shipped to consumers before stem elongation occurs (De Hertogh, 1996).

Control of postharvest stem stretch is of a greater concern to prevent unsightly stem elongation during marketing and to improve postharvest quality for consumers. Ideally, plants treated with PGRs should be at least $15 \%$ to $20 \%$ shorter than the untreated control at postharvest evaluation ( $\mathrm{T}$. Harger, personal communication). To provide postharvest control with 'Tete a Tete', a preplant soak of flurprimidol $\left(25 \mathrm{mg} \cdot \mathrm{L}^{-1}\right)$ or paclobutrazol $(75$ $\left.\mathrm{mg} \cdot \mathrm{L}^{-1}\right)$ can be used. Substrate drenches of flurprimidol $(0.69 \mathrm{mg} /$ pot a.i. $)$ or paclobutrazol ( $2 \mathrm{mg} /$ pota.i.) provided adequate control, as well as a foliar spray of ethephon $\left(1518.4 \mathrm{mg} \cdot \mathrm{L}^{-1}\right)$. Preplant bulb soaks of flurprimidol $\left(20 \mathrm{mg} \cdot \mathrm{L}^{-1}\right)$ or paclobutrazol (100 $\mathrm{mg} \cdot \mathrm{L}^{-1}$ ) can be used to obtain 'Dutch Master' plants that are $15 \%$ to $20 \%$ shorter than the untreated control at postharvest evaluation. Flurprimidol preplant bulb soaks $\left(37.5 \mathrm{mg} \cdot \mathrm{L}^{-1}\right)$ can also be used to obtain commercially acceptable 'Sweetness' plants.
The responses of 'Tete a Tete', 'Dutch Master', and 'Sweetness' vary for flurprimidol as a preplant bulb soak. 'Tete a Tete' and 'Dutch Master' responses also vary for preplant bulb soaks of paclobutrazol. Cultivar response variation to PGRs has also been reported with sunflower (Helianthus annuns) (Whipker and McCall, 2000), hyacinth, and tulip (Tulipa spp.) cultivars (Krug, 2004). Therefore, growers should conduct on-site trials to determine the optimal concentrations for other narcissus cultivars.

\section{Literature cited}

Adriansen, E. 1985. Kemisk vaelstrugulering, p. 142-162. In: O.V. Christensen, A. Klougart, I.S. Pedersen, and K. Wikesojo (eds.). Potteplanter I-Produktion, Metoder, Midler. GartnerINFO, Kobenhavn, Denmark.

Briggs, J.B. 1975. The effects on growth and flowering of the chemical growth regulators ethephon on narcissus and ancymidol on tulip. Acta Hort. 47:287-296.

Cox, F.R. 1992. Range in soil phosphorus critical levels with time. Soil Sci. Soc. Amer. J. 56:1504-1509.

De Hertogh, A. 1996. Potted daffodils (Narcissus), p. B69-83. Holland bulb forcer's guide. Intl. Flower Bulb Ctr., Hillegom, The Netherlands.

Kamp, M. and A.A. De Hertogh. 1986. Anatomical and growth effects of ethephon on hyacinths and narcissus during greenhouse forcing. Scientia Hort. 29:263-272.

Krug, B.A. 2004. The chemical growth regulation of bulb crops using flurprimidol as foliar sprays, substrate drenches, and preplant bulb soaks. MS Thesis. North Carolina State Univ., Raleigh.

Moe, R. 1980. The use of ethephon for control of plant height in daffodils and tulips. Acta Hort. 109:197-204.

Whipker, B.E. and I. McCall. 2000. Response of potted sunflower cultivars to daminozide foliar sprays and paclobutrazol drenches. HortTechnology 10:209-211. 